\title{
Effect of Cr Additions on Ferrite Recrystallization and Austenite Formation in Dual-Phase Steels Heat Treated in the Intercritical Temperature Range
}

\author{
José Francisco da Silva Filho ${ }^{a}$, Carlos Augusto Silva de Oliveira ${ }^{b}$, Nina Fonstein ${ }^{c}$, Olga Girina ${ }^{c}$, \\ Fabiano José Fabri Miranda ${ }^{a}$, Juliovany Drumond ${ }^{a}$,Eder Adolfo Serafim ${ }^{a}$, \\ Conrado Ramos Moreira Afonso \\ ${ }^{a}$ ArcelorMittal Vega, São Francisco do Sul, SC, Brazil \\ ${ }^{b}$ Department of Materials Engineering, Universidade Federal de Santa Catarina - UFSC, SC, Brazil \\ ${ }^{c}$ ArcelorMittal Global R\&D, East Chicago, USA \\ ${ }^{d}$ Department of Materials Engineering - DEMa, Universidade Federal de São Carlos - UFSCar, \\ São Carlos, SP, Brazil.
}

Received: October 10, 2015; Accepted: December 16, 2015

\begin{abstract}
An experimental investigation was conducted using laboratory-processed low carbon Mn-Mo-Nb-Ti-B dual phase steel with additions of $0.2 \mathrm{Cr}$ or $0.6 \% \mathrm{Cr}$. This study investigates the effect of $\mathrm{Cr}$ additions on ferrite recrystallization and austenite formation during continuous annealing in the intercritical temperature range. It was found that moderate additions of $\mathrm{Cr}(0.2 \%)$ accelerates the ferrite recrystallization (nucleation and growth) resulting in coarse ferrite grains. An increase in $\mathrm{Cr}$ content up to $0.6 \%$ also accelerates the ferrite recrystallization which in addition to the presence of $\mathrm{Cr}$-rich carbides facilitates the austenitization predominantly through the nucleation process resulted in finer austenite grains. Thereby, the higher $\mathrm{Cr}$ content increases the volume of homogenized and refined martensite in the final quenched structure.
\end{abstract}

Keywords: Dual phase steel, Recrystallization, Phase transformation, Intercritical temperature range, Cr effects

\section{Introduction}

Increased emphasis on crash worthiness in combination with weight reduction has prompted automotive manufacturers to search for steels with much better mechanical properties, what pushes the steels producers in the direction of the development of the Advanced High Strength Steels (AHSS) of low cost. It has been shown that the addition of alloy elements such as $\mathrm{Si}$, Mo and $\mathrm{Cr}$ in high strength steels is very effective in improving the strength ductility balance ${ }^{1-3}$, through microstructure optimization. The detailed mechanism of these alloying elements, $\mathrm{Cr}$ effect in particular on final structure, is not fully understood. As the final microstructure is strongly dependent on the austenite formation during annealing the evaluation of austenite formation affected by $\mathrm{Cr}$ addition are of fundamental importance ${ }^{4-8}$. The austenite formation depends on several factors such as an initial microstructure, degree of ferrite recrystallization, carbon distribution and homogeneity of individual phases. The role of the carbide particles, Crcarbides in particular, should be taken into account too. During intercritical annealing, a complex interaction between recrystallization, grain growth, and phase transformation occurs ${ }^{9,10}$. The degree of such interplay depends, first of all, on the chemical composition of the steel (e.g., microalloying additions) and processing parameters ${ }^{8,11,12}$. In this way, the present study attempts to investigate the effect of $\mathrm{Cr}$ addition on the final microstructure of Mn-Mo-Nb-Ti-B dual-phase

*e-mail: jose.francisco@arcelormittal.com.br steels that presents typical composition of higher strength DP steels. Thereby, the investigation will address the ferrite recrystallization, phase transformation (austenite nucleation and growth) during annealing and emphasize the role of $\mathrm{Cr}$ carbides. The effect of $\mathrm{Cr}$ on stability of austenite in cooling will be presented separately.

\section{Materials and Methods}

\subsection{Material}

Table 1 lists the chemical composition of the steels investigated.

Three vacuum-induction-melted heats of $45 \mathrm{~kg}$ were prepared with the chemical compositions shown in Table 1. The ingots were reheated and hot-rolled into plates using a laboratory hot mill. Hot rolling was conducted in two steps. The ingots, reheated at $1250^{\circ} \mathrm{C}$, were hot-rolled into plates of 20 -mm thickness. Plates, in turn, were reheated again at 1200 ${ }^{\circ} \mathrm{C}$ and processed into hot-rolled sheets of $3.0 \mathrm{~mm}$ gauge with finishing rolling temperature of $880^{\circ} \mathrm{C}$, followed by laminar water cooling on the run out table to $650{ }^{\circ} \mathrm{C}$. In order to simulate the coiling process, hot rolled sheets were transferred to a furnace with a controlled Ar atmosphere, held for $1 \mathrm{~h}$ at $650{ }^{\circ} \mathrm{C}$, and cooled to room temperature within the furnace at $\sim 30^{\circ} \mathrm{C}$ per hour. Hot-rolled sheets were ground on both sides to ensure a decarburized-free surface, followed by cold 
rolling with about $60 \%$ reduction to $1.25-\mathrm{mm}$ gauge. The full hard steel was cut into coupons for follow-up heat treatments.

It is worthy to note that chemical composition of investigated steels resulted, after cold rolling, in a microstructure with a complex phase matrix. Fig. 1 presents the microstructures of cold rolled steels used for the heat treatment. It shows the presence of elongated grains of ferrite and carbon containing constituents (degenerate "pearlite" and islands of "martensite"). As can be seen, additions of $0.2 \%$ of $\mathrm{Cr}$ increase the volume of carbon containing constituents. Further increase in $\mathrm{Cr}$ content up to $0.6 \%$ increases the amount and homogeneity of martensite islands facilitating more uniform distribution of carbon in ferritic matrix.

\subsection{Experimental Procedure}

\subsubsection{Heat Treatment}

Cold rolled samples were dipped into a salt bath and heated up to temperatures in the intercritical $(\alpha+\gamma)$ region $\left(\sim 50^{\circ} \mathrm{C} / \mathrm{s}\right.$ heating rate), held isothermally at selected temperature for 60 seconds followed by quenching into a water tank (Fig. 2).

Table 1. Chemical composition (weight per cent).

\begin{tabular}{ccccccccccccc}
\hline Steels & C & Mn & Cr & Mo & Nb & Ti & Al & P & 0.042 & 0.004 & 0.009 & 0.0012 \\
\hline A (0.0Cr) & 0.083 & 2.08 & 0 & 0.16 & 0.015 & 0.031 & 0.042 & 0.038 & 0.004 & 0.007 & 0.0011 \\
B (0.2Cr) & 0.084 & 2.07 & 0.22 & 0.15 & 0.014 & 0.031 & 0.038 \\
C (0.6Cr) & 0.086 & 2.09 & 0.62 & 0.15 & 0.013 & 0.027 & 0.043 & 0.003 & 0.008 & 0.0012 \\
\hline
\end{tabular}
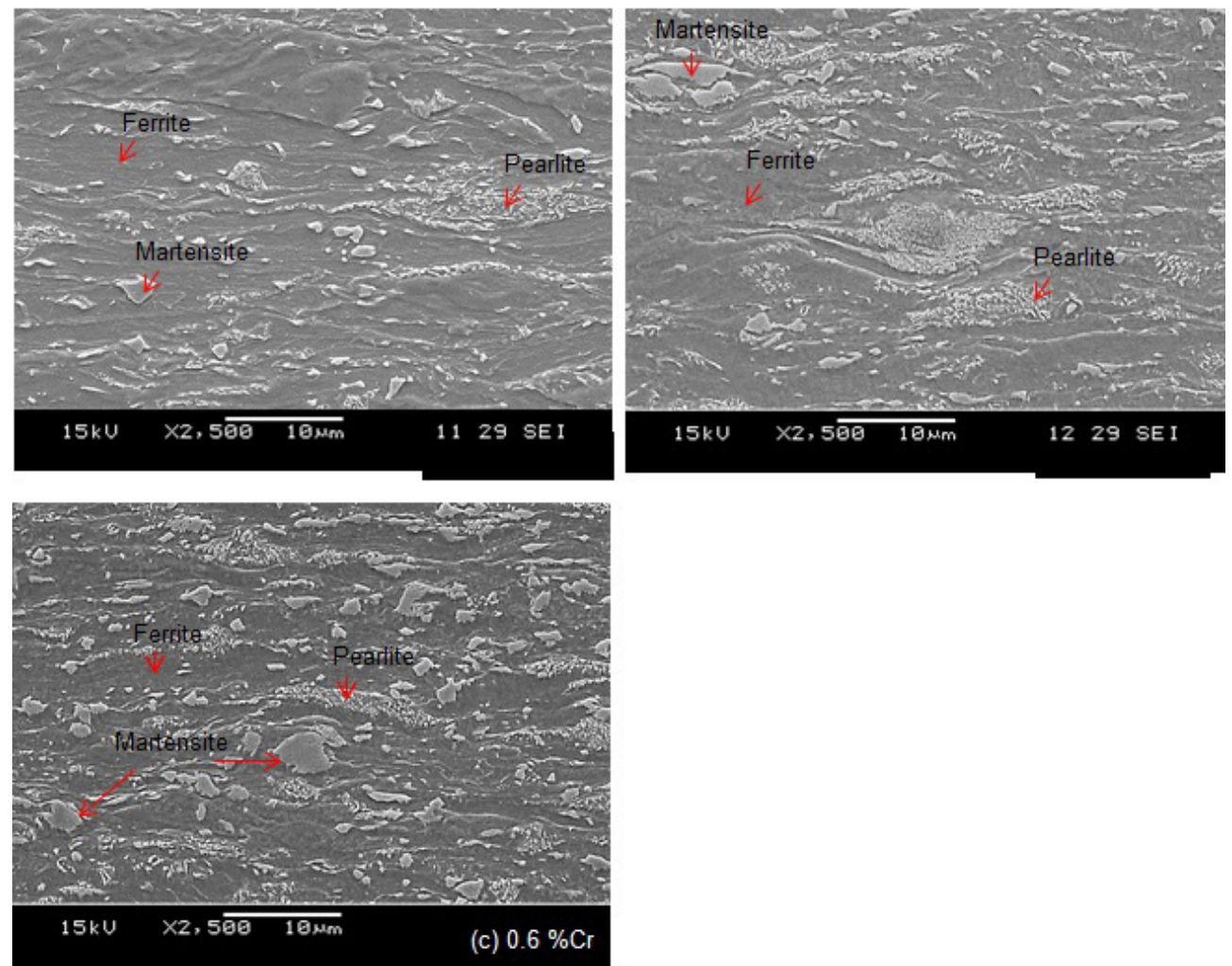

Fig. 1. Initial microstructures of cold rolled steels with different chromium content (before annealing).
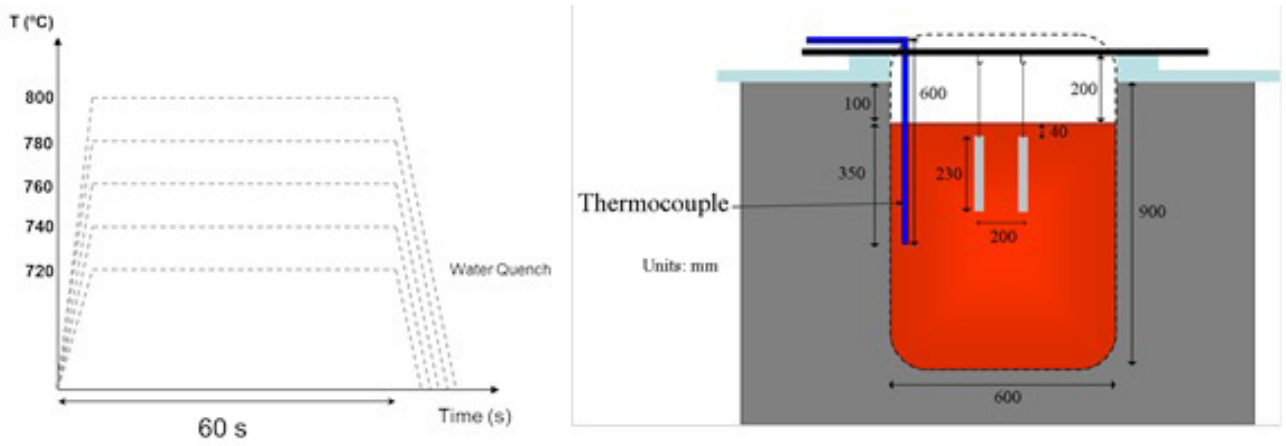

Fig. 2. (a) Thermal Cycle and (b) Salt Bath Furnace. 
The soaking temperatures varied from 720 to $800{ }^{\circ} \mathrm{C}$ with the step of $20^{\circ} \mathrm{C}$. After heat treatment 3 samples from each condition were prepared for further microstructure analysis.

The salt bath was composed of barium chloride $\left(\mathrm{BaCl}_{2}\right)$ and heated by natural gas system. Bath temperature upon annealing was strictly controlled by thermocouples installed in the furnace wall ${ }^{12}$.

Water quenching of annealed samples was aiming to observe the processes of ferrite recrystallization and austenite formation at specific temperature, when martensite in the final structure reflected morphology and amount of austenite.

\subsubsection{Microstructure Characterization}

The microstructure of heat-treated steels was characterized by using SEM, FEG-SEM, TEM and EBSD technique. The quantification of microstructure constituents was developed in a SEM Jeol6360. The microstructure characterization was developed by using an SEM-FEG Zeiss EVO-MA-15 and TEM/STEM FEI Tecnai G2 200kV equipped with EDS (EDAX DX-4).

Microstructural analyses were conducted on the longitudinal section at $1 / 4$ of thickness, using etching in $4 \%$ Nital.

Volume fractions of martensite were measured manually by point counting using a grid containing 920 small meshes. Three measurements per sample were taken at different regions along the $1 / 4$ of thickness, and the average amount was considered.

The average sizes of martensite islands were determined by using the Axion Vision Zeiss analysis system based on around the 550 measurement per sample.

The TEM analysis was performed on carbon replicas and also on thin films taken from samples of steels without $\mathrm{Cr}$ and with $0.6 \% \mathrm{Cr}$, after heat treatment at 720,740 and $780^{\circ} \mathrm{C}$.

\section{Results and Discussion}

The discussed results include two different aspects, microstructural analysis focusing on the evolution of ferrite and austenite morphology with $\mathrm{Cr}$ concentration and temperature; and behavior of carbides as a function of annealing temperature and concentration of $\mathrm{Cr}$.

\subsection{Microstructural Analysis of Investigated Steels and Effects of Cr Content and Temperature}

Hereafter discussion addressing ferrite recrystallization and phase transformation will be developed based on the microstructures of steels presenting (Fig. 3 to 10), related to steels containing different concentration of $\mathrm{Cr}$ annealed at several different temperatures.

The comparison of microstructures of steels annealed at $720^{\circ} \mathrm{C}$ (Fig. $3 \mathrm{a}-\mathrm{e}$ ) with cold rolled microstructures presented in Fig. 1 shows that carbon containing constituents such as martensite and pearlite (carbide + ferrite) are mostly dissolved during heating treatment but carbides dissolve differently depending on chromium concentrations. Fig. 3 (b and c) shows the presence of some recrystallized ferrite grains simultaneously with some martensite at the grain boundaries (former austenite), which suggest the overlapping of phenomena (recrystallization and transformation) for steels containing chromium ${ }^{13}$. On the other hand, the microstructure of Cr-free steel shows the presence of non-recrystallized ferrite without significant phase transformations (Fig. 3 a and d). This difference in recrystallization rate of ferrite due to addition of Cr is clearly shown in Fig. 3 ("d" compared with "e"); as well as the presence of martensite "prior austenite" and undissolved coarse carbides in steel with $0.6 \%$ of $\mathrm{Cr}$.
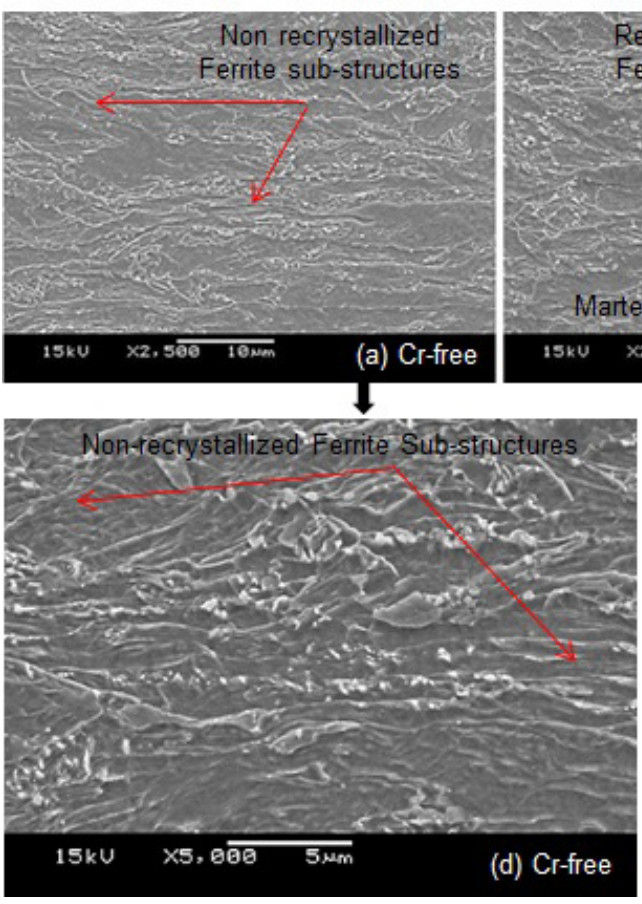
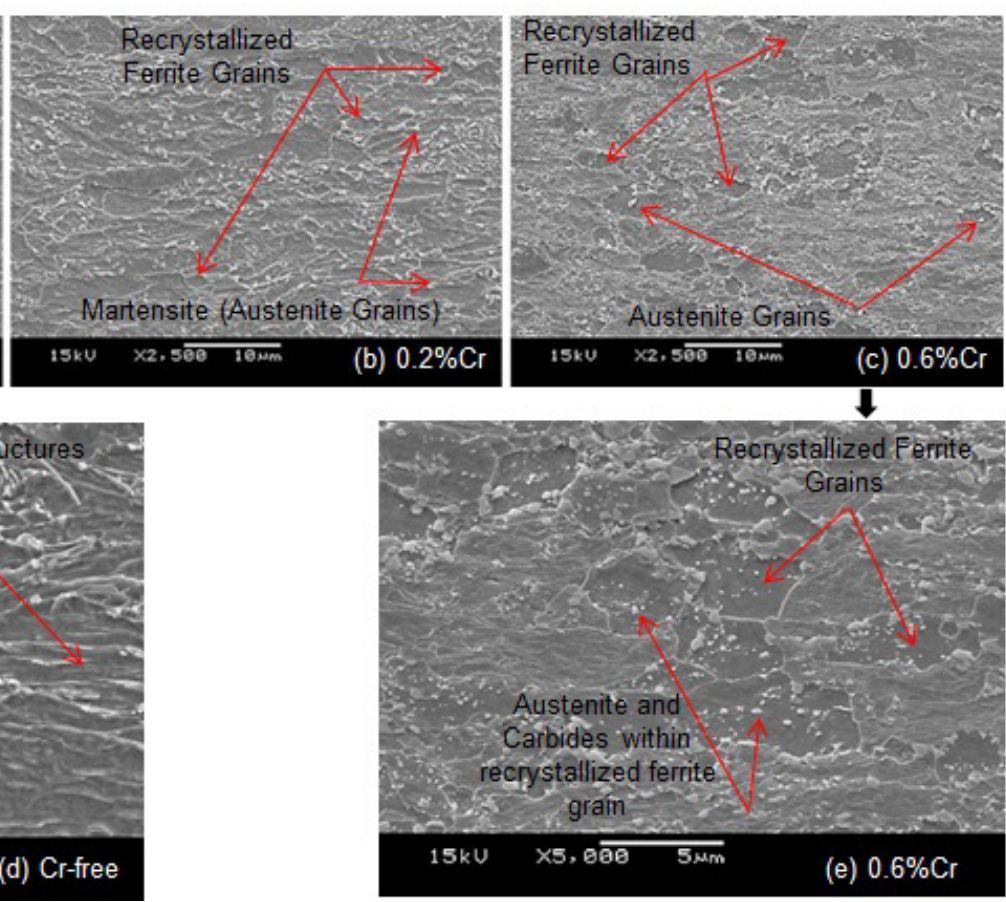

Fig. 3. Microstructure of steels (a, d) Cr-free, (b) $0.2 \% \mathrm{Cr}$ and (c, e) $0.6 \% \mathrm{Cr}$ annealed at $720^{\circ} \mathrm{C}(60 \mathrm{~s})$. 
Details of these undissolved chromium rich carbides will be addressed later.

Further increase in annealing temperatures, above $720^{\circ} \mathrm{C}$, increases the driving force for the ferrite recrystallization, austenite formation and carbides dissolution.

At $740^{\circ} \mathrm{C}$ the presence of coarse recrystallized ferrite grains in the microstructure of steel with $0.2 \% \mathrm{Cr}$ confirms the effect of $\mathrm{Cr}$ additions on the acceleration of ferrite recrystallization (Figs. $4 \mathrm{~b}$ and 5b). It agrees with the concept of $\mathrm{Cr}$ as an element for reducing the barrier of activation energy of growth $\left(\mathrm{N}_{\mathrm{G}}\right)$ and increasing the thermodynamic potential of transformation ${ }^{14,15}$.

Further additions of $\mathrm{Cr}$ in the steels $(0.6 \%)$ also accelerate the ferrite recrystallization mainly through the nucleation process that is observed in Figs. 4c and 5c through the refinement of the microstructure.
It should be note that at $740^{\circ} \mathrm{C}$ the microstructures of martensite islands (prior austenite) are found, predominantly, at different positions in relation to the ferrite matrix depending on Cr content in the steels: i) along the "ferrite non-recrystallized substructure boundaries" in Cr-free steels (Fig. 4a); ii) along the grain boundaries of coarse recrystallized ferrite in steels with $0.2 \% \mathrm{Cr}$ additions (Fig. $4 \mathrm{~b}$ ); and iii) uniformly distributed (along the grain boundaries of fine grains and inside the grains) in steels with $0.6 \% \mathrm{Cr}$ additions (Fig. $4 \mathrm{c}$ ).

Fig. 5 shows the microstructures of steels with different Cr concentrations, obtained by EBSD (IPF) after annealing at $740^{\circ} \mathrm{C}$ : i) the $\mathrm{Cr}$-free steel shows regions of non-recrystallized elongated grains, predominantly, with a few fine recrystallized grains (Fig. 5a); ii) the additions of $0.2 \% \mathrm{Cr}$ resulted in the appearance of regions with predominantly coarse recrystallized ferrite grains, in the presence of few fine grains (Fig. 5b);
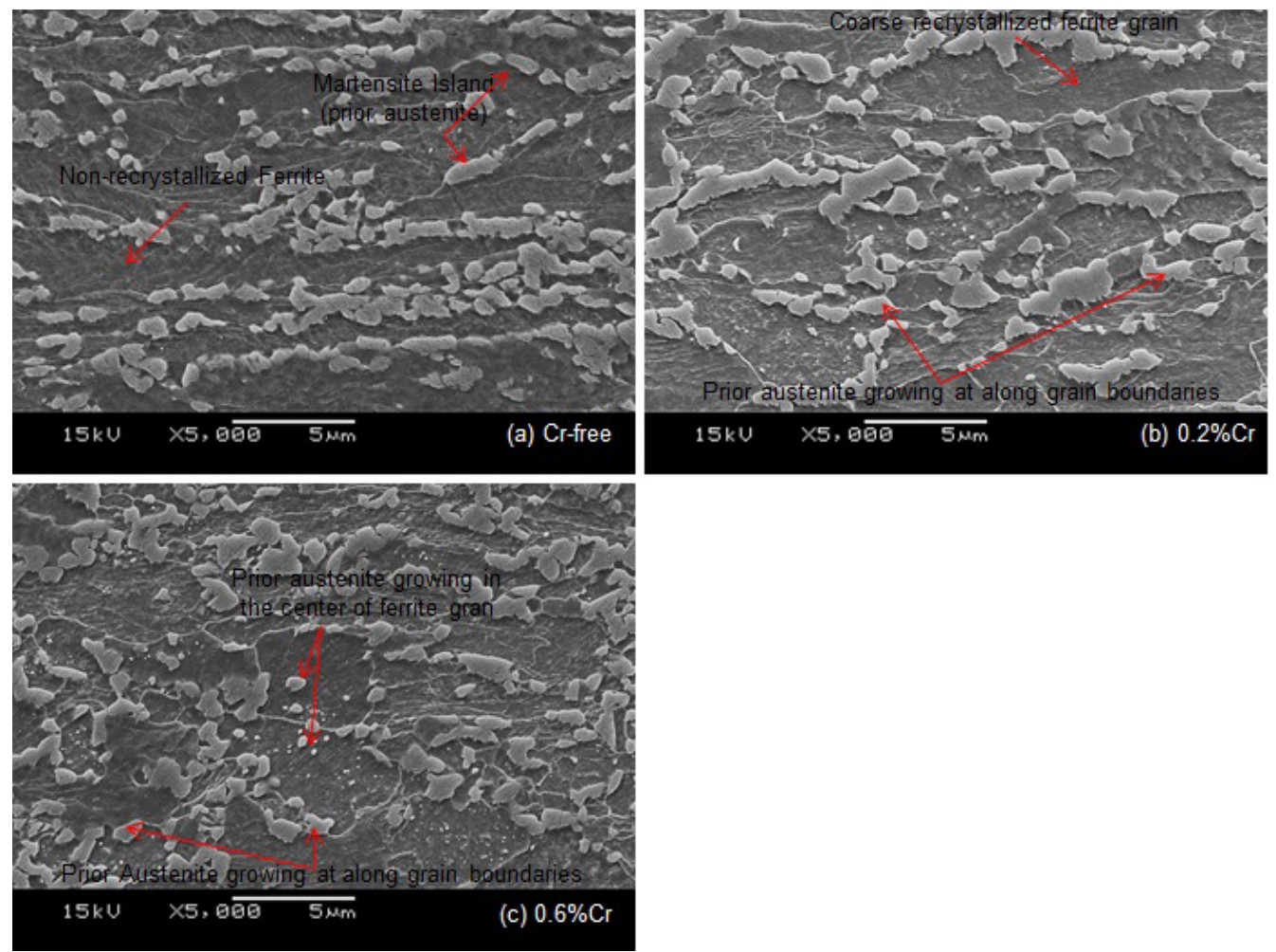

Fig. 4. Microstructures of steels: (a) $\mathrm{Cr}-\mathrm{free}$, (b) $0.2 \% \mathrm{Cr}$ and (c) $0.6 \% \mathrm{Cr}$ steels annealed at $740^{\circ} \mathrm{C}(60 \mathrm{~s})$.

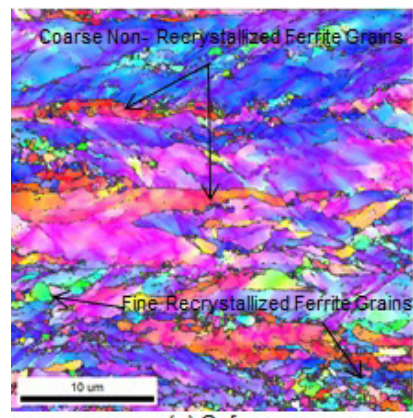

(a) $\mathrm{Cr}$ free

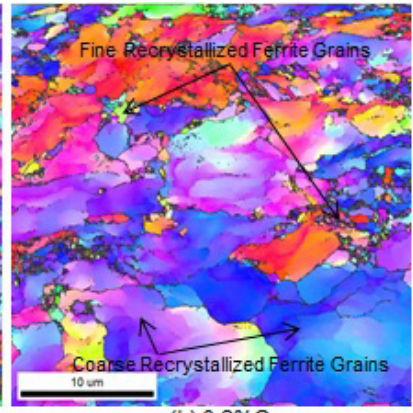

(b) $0.2 \% \mathrm{Cr}$

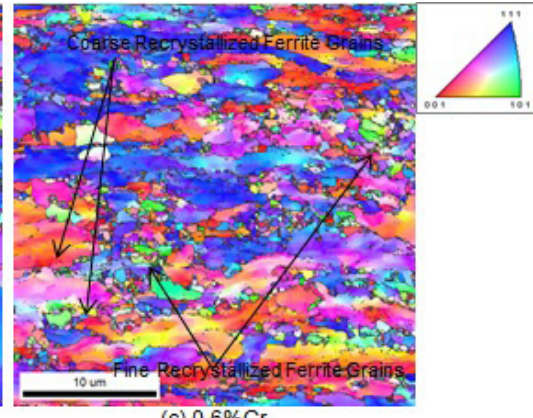

(c) $0.6 \% \mathrm{Cr}$

Fig. 5. Effect of $\mathrm{Cr}$ on the ferrite recrystallization and growth at $740{ }^{\circ} \mathrm{C}$. 
iii) the additions of $0.6 \% \mathrm{Cr}$ resulted in the appearance of regions with predominantly fine recrystallized grains mixed with few coarse grains. The major refinement of ferrite grains in the steel with $0.6 \% \mathrm{Cr}$ suggests that the higher chromium contents favors the recrystallization acceleration affecting grain nucleation but simultaneously preventing the ferrite grains growth (see Fig. 5b compared with 5c).

The observation of martensite (former austenite) growing in the center of the grains of $0.6 \% \mathrm{Cr}$ steel and its association with the presence of carbides motivated the investigation of this phenomenon.

It is worth to point out that experiments were developed in quenched condition to explore the final microstructure of both ferrite and austenite phases, reflected by the resultant structures as ferrite and martensite.

As an example, Fig. 6 displays a ferrite grain with the martensite located on the boundary and in the center, simultaneously. It displays also a martensite structure growing on the surface (on top) of one particle of chromium carbide in steel with additions of $0.6 \% \mathrm{Cr}$.

Fig. 6a shows the martensite (white) growing at the grain boundary and within the ferrite grain. Martensites within the grain were found frequently on the surface of chromium-rich carbide which confirms the occurrence of nucleation of austenite Fig. $6 \mathrm{~b}$ (the grey particle is the Cr-rich carbide and white structure is the martensite). This suggests that higher chromium concentrations promote the occurrence of chromium-rich carbides within the ferrite grains, which in turns act as a site for the austenite nucleation. This additional mechanism of nucleation and the growth of austenite within the ferrite grains affects the process of austenite formation resulting in the refinement of austenite grains (and therefore in refinement of martensite islands) (Figs. 4 b and c; Figs. 6 b and c).

Figs 7 to 10 will show the evolution of phase transformation and ferrite recrystallization with temperature and $\mathrm{Cr}$ content. At $760^{\circ} \mathrm{C}$ the volumes of martensite increase regardless of $\mathrm{Cr}$ content as shown in Figs. 7 (microstructure) and 10 (quantification graphic), in comparison with Fig. $4\left(740^{\circ} \mathrm{C}\right)$. These increases in the amount of martensite are likely due to a few factors including: i) the increase of nucleation rate of austenite at the "ferrite non-recrystallized substructure boundaries" of Cr-free steels (Fig. 7a); ii) the increase of nucleation rate and growth of austenite along the "boundaries of coarse ferrite" and simultaneously the growth of austenite from the "boundaries to the inside of these ferrite grains" in the $0.2 \% \mathrm{Cr}$ steels (Fig. $7 \mathrm{~b}$ ); iii) the increase of nucleation rate and growth of austenite along the "boundaries of fine recrystallized ferrite" simultaneously with the growth of austenite from the "boundaries to the inside of these grains" combined with the nucleation and growth of austenite grains "on the surface of carbides" present inside the grains for the $0.6 \% \mathrm{Cr}$ steels (Figs. 3e and 7c). The structure of nucleation in $0.6 \%$ steel is shown in detail in Fig. 6. At this point, it is worth mentioning that the nucleation on the surface of carbides plays an important role as an additional mechanism of austenite refinement.

At $780^{\circ} \mathrm{C}$ the volumes of martensite (austenite) increase also regardless of concentrations of $\mathrm{Cr}$, as shown in Fig. 8. The process of phase transformation overcomes the recrystallization. Some changes are observed in the microstructures with the increase in temperature: i) the growth of austenite at the "ferrite non-recrystallized substructure boundaries" of Cr-free steels still proceeds since recrystallization is ongoing slowly (Fig. 8a); ii) the growth of austenite in steels with $0.2 \% \mathrm{Cr}$ proceeds prevailingly, from the "boundaries to the inside" of ferrite grains (radial growth) since these boundaries are almost fully covered by austenite and there is no more significant growth along them (Fig. 8b); and iii) the "radial growth" of austenite grains to the opposite directions is observed that means, growth from the "grain boundaries to inward" and from the "center of the grains to outward", in the $0.6 \% \mathrm{Cr}$ steels.

The grain growth that comes from the center to outward is a result of nucleation on the top of remaining chromium carbides present inside the ferrite grains (Fig. 6 a, b). The major refinement of martensite (prior austenite) island, observed in the steel with addition of $0.6 \% \mathrm{Cr}$, suggests that chromium (as carbides particles) acts favoring an additional nucleation of austenite on the top of particles. This additional nucleation of austenite increases the total nucleation rate creating more nuclei within the ferrite grains; which in turn causes the refinement of austenite (martensite).

Similarly to Fig. 5 the Fig. 9 shows the microstructures of steels with different $\mathrm{Cr}$ concentrations, obtained by EBSD (IPF) depicting details of recrystallization stage and

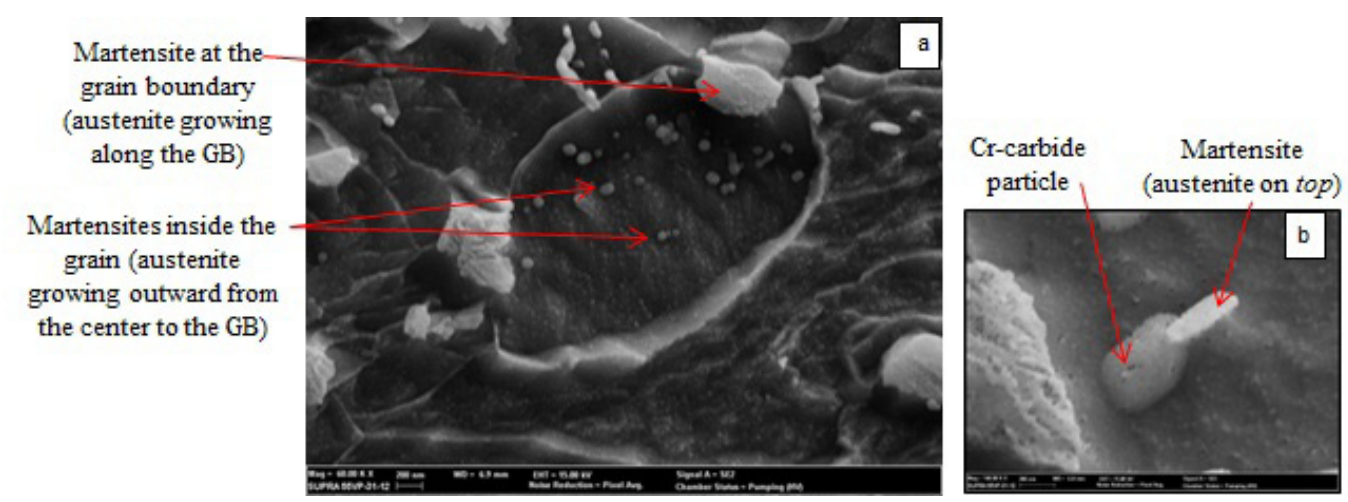

Fig. 6. Microstructure of ferrite grain of a steel with $0.6 \%$ of $\mathrm{Cr}$ at $740^{\circ} \mathrm{C}$, (a) showing the nucleation of austenite (final martensites) at different positions of the grain (inside and at GB); (b) an example of particles found inside the ferrite grains showing the austenite nucleation on $\mathrm{Cr}$ carbide as on substrate. 

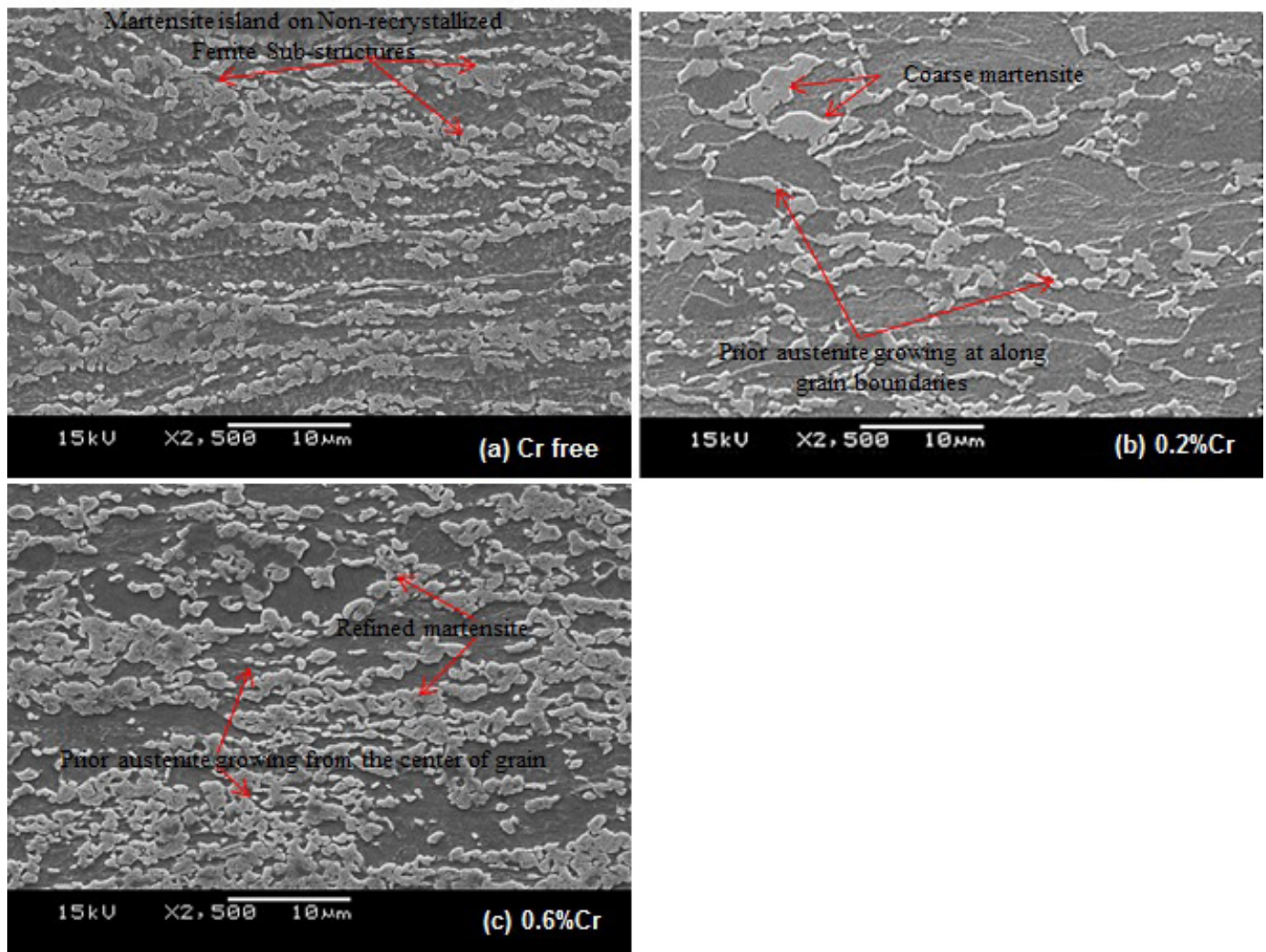

Fig. 7. Microstructure of steels: (a) $\mathrm{Cr}$-free, (b) $0.2 \% \mathrm{Cr}$ and (c) $0.6 \% \mathrm{Cr}$ steels, annealed at $760^{\circ} \mathrm{C}(60 \mathrm{~s})$.
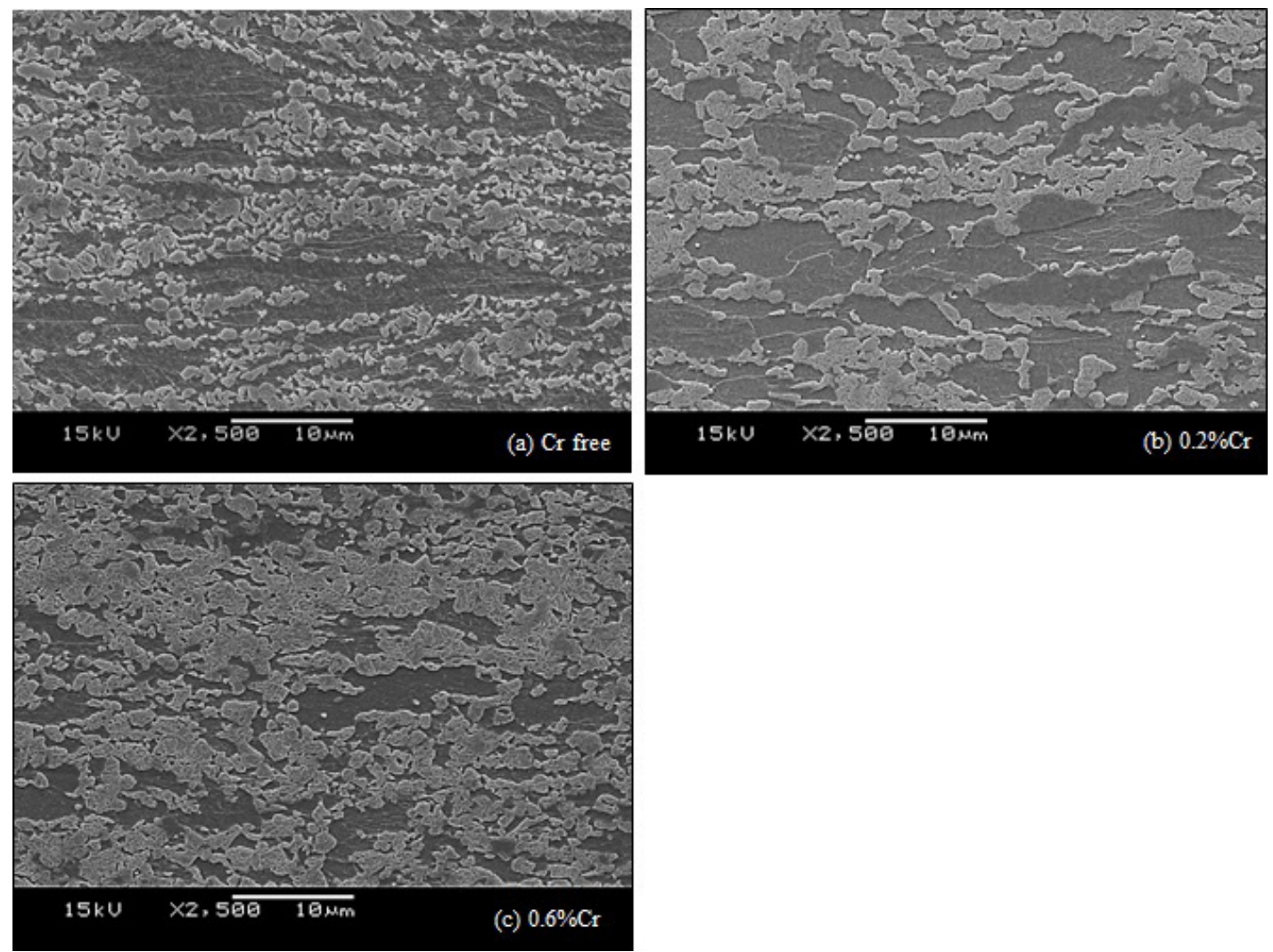

Fig. 8. Microstructure of steels (a) $\mathrm{Cr}$-free, (b) $0.2 \% \mathrm{Cr}$ and (c) $0.6 \% \mathrm{Cr}$, annealed at $780^{\circ} \mathrm{C}(60 \mathrm{~s})$. 


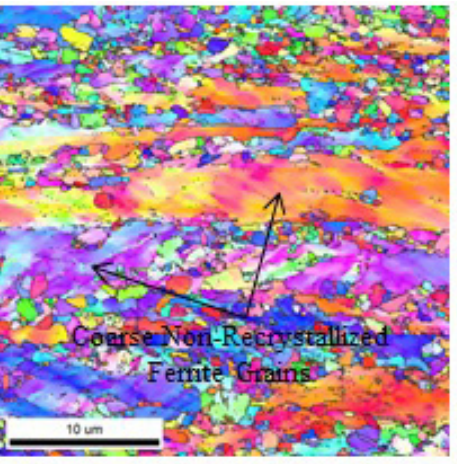

(a) $\mathrm{Cr}$-free

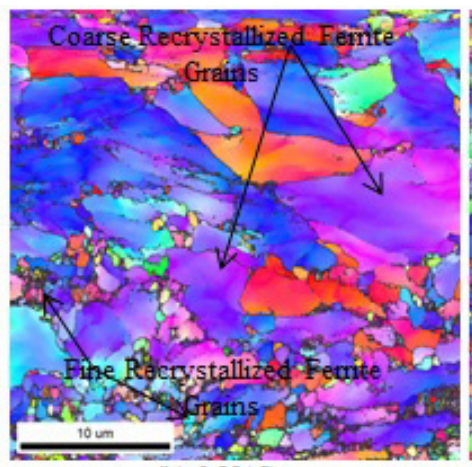

(b) $0.2 \% \mathrm{Cr}$

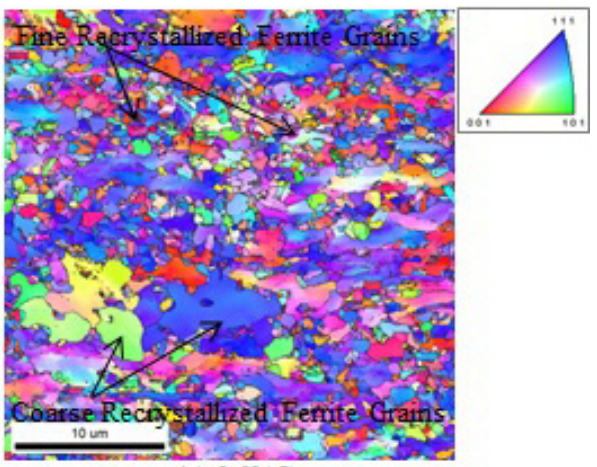

(c) $0.6 \% \mathrm{Cr}$

Fig. 9. Effect of $\mathrm{Cr}$ on the ferrite recrystallization and growth as $780^{\circ} \mathrm{C}$.

coarsening or refinement of ferrite grains after annealing, however at $780^{\circ} \mathrm{C}$. The $\mathrm{Cr}$-free steels show, predominantly, non-recrystallized elongated substructures with some few fine recrystallized grains (Fig. 9a). The addition of $0.2 \% \mathrm{Cr}$ to the steels resulted in the appearance of regions with mostly coarse recrystallized grains with few fine grains (Fig. 9b). The addition of $0.6 \% \mathrm{Cr}$ to the steels resulted in the appearance of regions of fine recrystallized grains mixed with some coarse grains. The major refinement of ferrite grains in the steel with addition of $0.6 \% \mathrm{Cr}$ shows that the higher chromium concentration favors the more amount of centers for nucleation suggests a probable additional mechanism for preventing the ferrite grains from growing (Fig. 9b compared with 9c).

\subsection{Quantification of Martensite Phase to Characterize Austenite Formation}

The effect of $\mathrm{Cr}$ concentration and annealing temperature on the volume of martensite (prior martensite) is shown in Fig. 10 pointing at different rate of austenitisation. To obtain around $30 \%$ of martensite in the $\mathrm{Cr}$-free steel it is necessary to reach the annealing temperature of around $760^{\circ} \mathrm{C}$ whereas the steel with addition of $0.6 \% \mathrm{Cr}$ it is obtained at around $740^{\circ} \mathrm{C}$. It confirms the accelerating effect of $\mathrm{Cr}$ on the kinetics of austenitisation. The more the volume of austenite the more is the volume of transformed martensite after fast cooling, and consequently results in higher strength of steels.

It is observed that the average size of martensite islands in steels with $0.6 \% \mathrm{Cr}\left(0.76 \mu \mathrm{m}^{2}\right)$ is smaller and more uniform than the ones in Cr-free steels $\left(0.95 \mu \mathrm{m}^{2}\right)$. This agrees with microstructures shown in Figs 4 and 7.

It is important to note that the steel with addition of $0.6 \%$ $\mathrm{Cr}$ exhibits microstructure more refined then the one with moderate addition of $0.2 \%$ Cr Fig. 7 ("b" and "c" respectively) due to the nucleation process which leads to the microstructure refinement including the role of $\mathrm{Cr}$ carbides that can also act as a substrate for austenite nuclei ${ }^{16}$.

The Cr-rich carbides present in the initial structure within the ferrite grains promote the formation of austenite nuclei and subsequently the volume of martensite formed during cooling is increased and martensite islands are refined.

\subsection{Characterization of Carbides}

The significant effect of chromium on the ferrite recrystallization and phase transformation makes necessary to take into account the dissolution of the carbides with

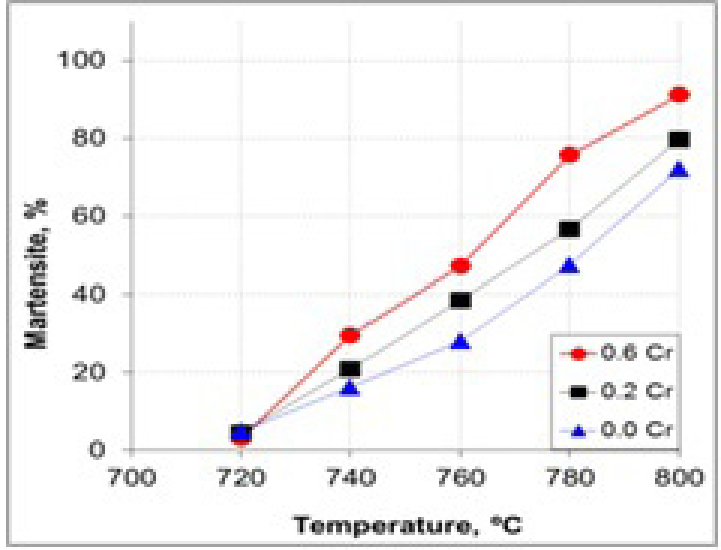

Fig. 10. Effect of $\mathrm{Cr}$ on the volume of martensite (percentage) as a function of annealing temperature.

temperature. Fig. 11 illustrates the dissolution of carbides, Cr-containing (11 a-c) and Cr-free (11 d-f), with temperature from 720 to $780^{\circ} \mathrm{C}$. As shown, some carbides dissolve rapidly with the increase in temperature, while others keep stables or dissolves slowly. This observation is confirmed by carbides particles extracted on carbon replica with following analysis on TEM.

At $720^{\circ} \mathrm{C} \mathrm{Cr}$-rich steels have more significant amount of carbide particles than the $\mathrm{Cr}$-free steels as shown by the circles (Fig. $11 \mathrm{a}$ and d). From 720 to $780^{\circ} \mathrm{C}$ the dissolutions of carbides proceed with different kinetics determined by the chromium content in the steels. As result, the presence of $\mathrm{Cr}$ in steels can catch some carbon atoms and inhibit their diffusion to grain boundaries.

Figs. 3 and 6 display the presences of carbides within the ferrite grains of steels with addition of $0.6 \% \mathrm{Cr}$, which were confirmed by SEM/EDS and carbon replica analysis on STEM. SEM/EDS analysis showed the presence of Cr, Mn and Fe in particles (Fig. 11b), while STEM the structures of $\mathrm{M}_{3} \mathrm{C}, \mathrm{M}_{7} \mathrm{C}_{3}, \mathrm{M}_{23} \mathrm{C}_{6}$ (Cr-rich carbides where $\mathrm{M}$ can be Fe, $\mathrm{Cr}$, Mo, Mn), Fig. 12 a,b. TiN undissolved particles are present on every replica.

At $740^{\circ} \mathrm{C}$ the more stable $\mathrm{Cr}$-rich carbides $\left(\mathrm{M}_{7} \mathrm{C}_{3}, \mathrm{M}_{23} \mathrm{C}_{6}\right)$ still remain, whereas the less stable carbides like $\mathrm{Fe}_{3} \mathrm{C}$ has already dissolved, almost completely, for both kinds of steels 


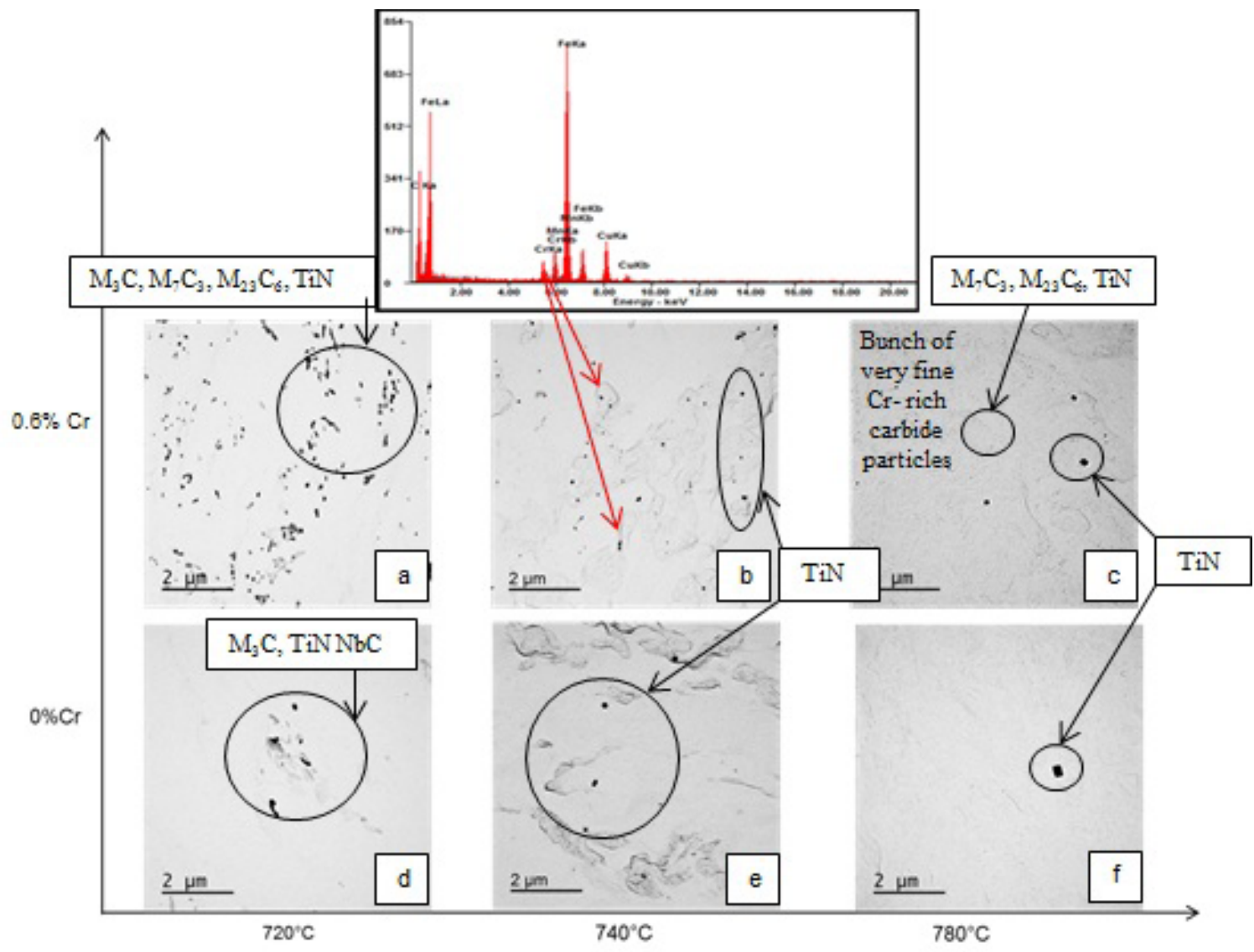

Fig. 11. Precipitation extracted from steels with $0.6 \%$ and $\mathrm{Cr}$-free at different annealing temperatures (carbon replica) including spectrogram of EDS of the Cr-rich carbides.
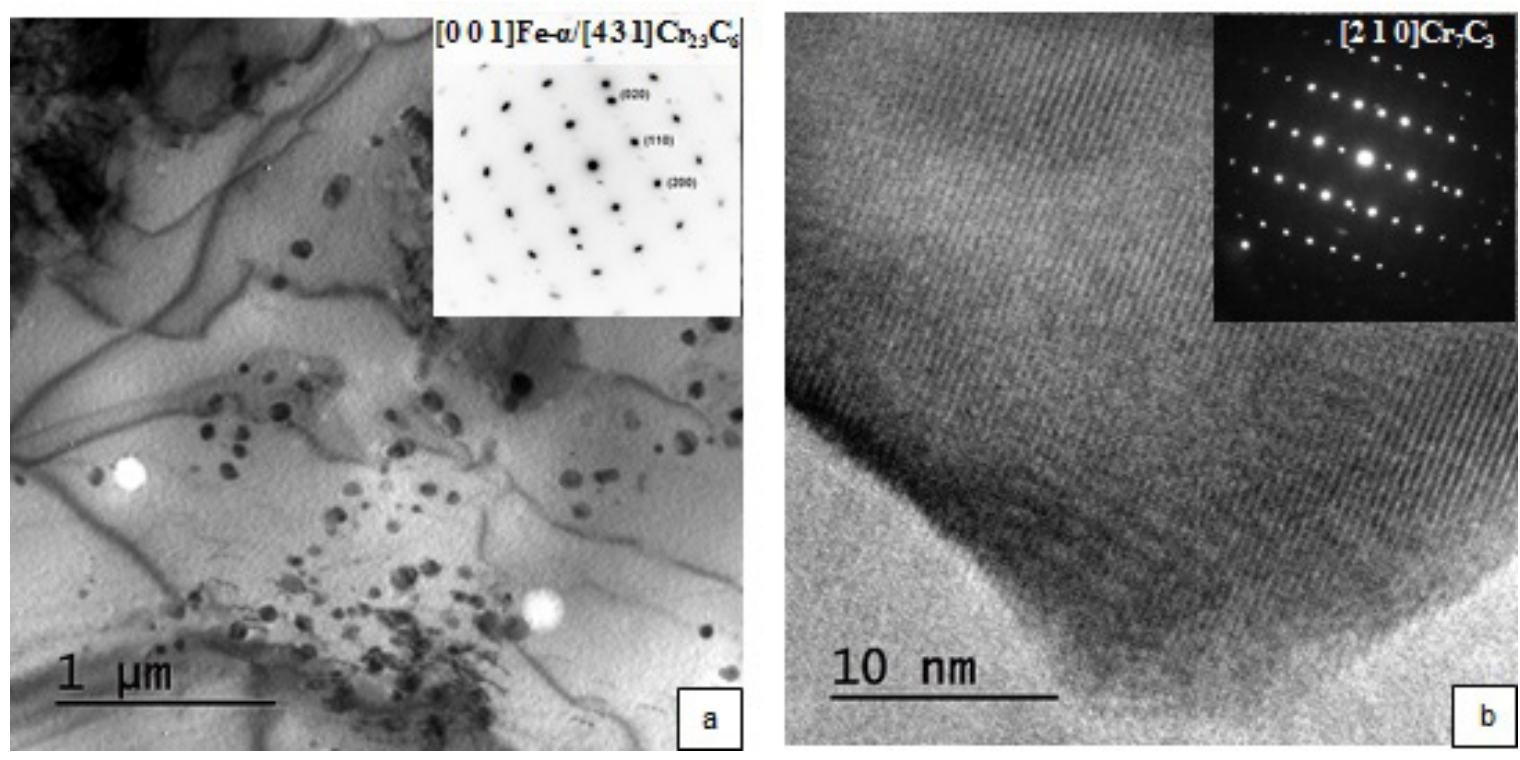

Fig. 12. Micrographs of particles found on steels with additions of $0.6 \% \mathrm{Cr}$ and annealed at $780{ }^{\circ} \mathrm{C}$. a) TEM bright field (BF) micrograph showing near spherical morphology carbides dispersed through the ferrite (Fe- $\alpha$ ) matrix, together with the selected area diffraction (SAD) showing orientation relationship between the $\left.\left[\begin{array}{lll}0 & 0 & 1\end{array}\right] \mathrm{Fe}-\alpha /\left[\begin{array}{lll}4 & -3 & -1\end{array}\right] \mathrm{Cr} 23 \mathrm{C} 620\right)$ and $b$ ) high resolution TEM image (HRTEM) showing interface between the $\mathrm{Fe}-\alpha$ matrix and the $\mathrm{Cr} 7 \mathrm{C} 3$ carbide with the respective selected area diffraction (SAD) in the $[210] \mathrm{Cr} 7 \mathrm{C} 3$ zone axis. 
(Fig. $11 \mathrm{~b}$ and e), respectively. The $\mathrm{M}_{7} \mathrm{C}_{3}$ and $\mathrm{M}_{23} \mathrm{C}_{6}$ were observed only in the steels with the addition of $0.6 \% \mathrm{Cr}$.

At $780^{\circ} \mathrm{C}$, with increase in hold temperature, the less stable carbides (e.g. $\left.\mathrm{Fe}_{3} \mathrm{C}\right){ }^{17}$, have completely dissolved and the remaining particles found on the analysis of extracted replica of steel with $0.6 \% \mathrm{Cr}$ showed $\mathrm{M}_{23} \mathrm{C}_{6}$ and $\mathrm{M}_{7} \mathrm{C}_{3}$ (Fig. 12).

Fig. 12 shows the results of TEM analysis on the carbon film containing the particles extracted from steels with $0.6 \%$ $\mathrm{Cr}$ heat treated at $780^{\circ} \mathrm{C}$, which confirms the presence of chromium carbides $\left(\mathrm{Cr}_{23} \mathrm{C}_{6}, \mathrm{Cr}_{7} \mathrm{C}_{3}\right)$ even at higher temperature $\left(780^{\circ} \mathrm{C}\right)$.

The presence of $\mathrm{Cr}_{23} \mathrm{C}_{6}$ at $780^{\circ} \mathrm{C}$ is evidenced on TEM bright field micrograph through the Selected Area Diffraction showing the orientation relationship between ferrite and the $\mathrm{Cr}_{23} \mathrm{C}_{6}$ planes (Fig. 12a).

The presence of $\mathrm{Cr}_{7} \mathrm{C}_{3}$ is evidenced on Fig. $12 \mathrm{~b}$ by the high resolution TEM image (HRTEM) showing the interface between the Fe- $\alpha$ matrix and the $\mathrm{Cr}_{7} \mathrm{C}_{3}$.

The presence of these both chromium carbides at high temperature confirms their higher stability due to effect of Cr presence.

\section{Conclusion}

The effect of $\mathrm{Cr}$ additions in low carbon intercritical annealed dual phase steels has been investigated using SEM, TEM and EBSD techniques. Recrystallization and phase transformation processes were observed through the evolution of microstructure with temperature observed after

\section{REFERENCES}

1. Bain EC. Functions of the alloying elements in steel. Chicago: American Society for Metals; 1945.

2. Hironaka S, Tanaka H, Matsumoto T. Effect of Si on mechanical property of galvannealed dual phase steel. Material Science Forum. 2010;638-642:3260-3265.

3. Davies RG. Influence of silicon and phosphorous on the mechanical properties of steels. Metallurgy Materials Transactions A. 1979;10:113-118.

4. Speich GR, Demarest VA, Miller RL. Formation of austenite during intercritical annealing of dual-phase steels. Metallurgy Materials Transactions A. 1981;12:1419-1428.

5. Garcia C, DeArdo AJ . Formation of austenite in 1,5 pct $\mathrm{Mn}$ steels. Metallurgical Transactions A. 1981A;12:521-530.

6. Cai XL, Garrat-Reed AJ, Owen WS. The development ofsome dual-phase steel structures from different starting microstructures. Metallurgical Transactions A. 1985A;16:543-557.

7. Caballero FG, Capdevila C, Garcia de Andrés C. Modelling of kinetics of austenite formation in steels with different initial microstructures. ISIJ International. 2001;41(10):1093-1102.

8. Souza MM, Guimarães JR, Chawla KK. Intercritical austenitization of two Fe-Mn-C steels. Metallurgical Transactions A. 1982;13A:575-579.

9. Doherty RD, Hughes DA, Humphreys FJ, Jonas JJ, Jensen DJ, Kassner ME, et al. Current issues in recrystallization: a review. Materials Science Engineering A. 1997;238(2): 219274. doi:10.1016/S0921-5093(97)00424-3 immediate water quenching. The presence of undissolved Cr-rich carbides was highlighted.

Chromium additions to the low carbon steels affect the initial hot and cold rolled structure promoting formation of refined grains of ferrite with uniform distribution of carbon containing phases; which in turn accelerate the recrystallization of ferrite and formation of austenite through the more intensive nucleation process.

Formation of stable chromium carbides in the steel with $0.6 \%$ of $\mathrm{Cr}$ suppresses the growth of recrystallized grains of ferrite and promotes additional substrates for austenite nucleation. It results in the refinement of microstructure and higher volume fraction of austenite to be transformed to martensite after fast cooling.

As shown, moderate additions of chromium ( $0.2 \%)$ favor the coarsening of ferrite grains.

Additions of chromium affect the kinetics of ferrite recrystallization and austenitization, due to delay of recrystallization of those two processes.

\section{Acknowledgement}

The authors would like to acknowledge ArcelorMittal (ArcelorMittal Vega and R\&D Chicago) for all support and permission to publish this paper; Prof. Dr. Marilena V. Folgueras (UDESC - Universidade do Estado de Santa Catarina) for allowing TEM analysis and Sociesc (Sociedade Educacional do Estado de Santa Catarina) for heat treatment contribution. C. A. S. Oliveira thank CNPq for grating the scholarship.

10. Ogawa T, Maruyama N, Sugiura N, Yoshinaga N. Incomplete recrystallization and subsequent microstructural evolution during intercritical annealing in cold-rolled low carbon steels. ISIJ International. 2010;50:469-475.

11. Huang J, Poole WJ, Militzer M. Austenite formation during intercritical annealing. Metallurgical and Materials Transactions A. 2004;35:3363-3375.

12. Drumond J, Girina O, Silva Filho JF, Fonstein N, Silva de Oliveira CA. Effect of silicon content on the microstructure and mechanical properties of dual-phase steels. Metallography Microstructure and Analysis. 2012;1(5):217-223. DOI: 10.1007/ s13632-012-0034-8

13. Oliveira MA, Jorge Jr AM, Balancin O. Influence of deformation on the kinetics of phase transformation in a forging steel during warm working. Materials Research. 2004;7(2):247-253. http:// dx.doi.org/10.1590/S1516-14392004000200006

14. Humphreys FJ, Hartherly M. Recrystallization and Related Annealing Phenomena. Oxford, UK; Pergamom; 1995.

15. Padilha AF, Siciliano Jr F. Encruamento, Recristalização, Crescimento de Grão e Textura. $3^{\mathrm{a}}$ ed. São Paulo: Associação Brasileira de Metalurgia e Materiais; 2005.

16. Song R, Ponge D, Kaspar R, Raabe D. Grain boundary characterization and grain size measurment in an ultrafinegrained steel. Zeitschrift fur Metallkunde. 2004;95:513-517.

17. Zhao L, Vermolen FJ, Wauthier A, Sietsma J. Cementite dissolution at $860^{\circ} \mathrm{C}$ in an Fe-Cr-C steel. Metallurgical and Materials Transaction A. 2006;37:1841-1850. 